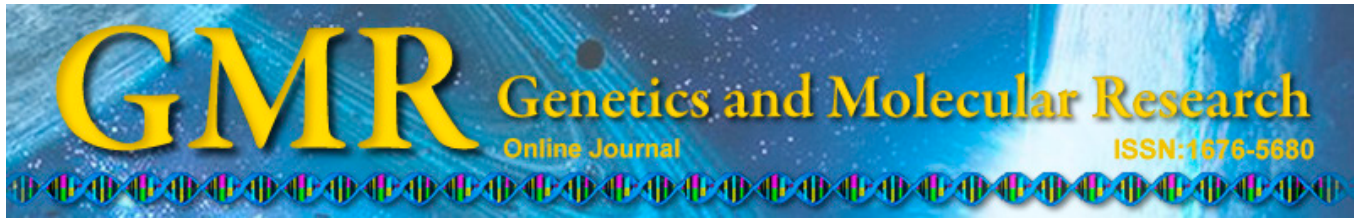

\title{
Genetic diversity of Qatari date palm using SSR markers
}

\author{
K. Elmeer ${ }^{1}$ and I. Mattat ${ }^{2}$ \\ Al Bayda, Libya \\ Corresponding author: K. Elmeer \\ E-mail: elmeer@gmail.com \\ Genet. Mol. Res. 14 (1): 1624-1635 (2015) \\ Received February 3, 2014 \\ Accepted July 2, 2014 \\ Published March 6, 2015 \\ DOI http://dx.doi.org/10.4238/2015.March.6.9
}

${ }^{1}$ Horticulture Department, Faculty of Agriculture, Omar Almukhtar University,

${ }^{2}$ Genetic Engineering Department, Biotechnology Centre, Doha, Qatar

\begin{abstract}
The genetic diversity in the date palm germplasm of 59 female accessions representing 12 cultivars from different locations in Qatar was investigated using 14 loci of simple-sequence repeat (SSR) primers. A total of 94 alleles, with a mean of 6.7 alleles per locus, were scored. The number of alleles per locus varied from 3 (primer mPdCIR090) to 11 (primers mPdCIR010 and mPdCIR015). The amplified SSR band sizes ranged from 104 to $330 \mathrm{bp}$. The mean gene diversity was 0.66 and ranged from 0.39 (locus mPdCIRO93) to 0.86 (locus mPdCIR015), indicating that the Qatari date palm collection has a high degree of genetic diversity. The heterozygosity ranged from 0 (marker mPdCIR090) to 98\% (marker mPdCIR010). Forty-four percent of the variability is explained at the inter-population level, while $56 \%$ of the variability is maintained within individuals. However, the loci mPdCIR044, mPdCIR057, mPdCIR090, and mPdCIR093 revealed that the total gene diversity is explained at the inter-population level. The Qatari populations Khalas, Shishi, Barhi, Hillali, Khnaizi, Gar, and Jabri showed significant differentiation compared to all other populations. The average fixation index was 0.24814 , showing that about $24.81 \%$ of
\end{abstract}


the genetic variation was present among populations, which correlated with analysis of molecular variance.

Key words: Date palm; Genetic diversity; Microsatellite markers; Phoenix dactylifera L.; Polymorphism

\section{INTRODUCTION}

Date palm (Phoenix dactylifera L.) is a long-lived, dioecious, monocotyledonous, fruit plant $(2 \mathrm{n}=36)$ belonging to the Arecaceae family (Barrow, 1998). It is believed to have originated in Mesopotamia, and thousands of cultivars have been reported (Hanachi et al., 1998). The genome size of date palms was estimated to be approximately between 550 and $650 \mathrm{Mbp}$ (Malek, 2010). In Qatar, about 447,821 date palms have been planted, which represent $80 \%$ of the total planted area. The date palms include 86 cultivars (54 internationally well-known cultivars and 32 Qatari cultivars). Cultivation mostly occurs in the north and middle areas of the state where environmental conditions are favorable and soil has a deep profile with low salinity compared to other parts of the country (Abulfatih et al., 1999; General Department for Agriculture Research and Development, 2008). Date palms have always been clonally propagated to ensure the identity and uniformity of the cultivars.

On the other hand, the conservation of date palm genetic resources has become an important issue regarding the development of date palm production (Oihabi, 2000) and food security in the desert and semi-desert areas of the country. The situation necessitates the evaluation of the genetic diversity of the current date palm cultivars and the preservation of the date palm germplasm worldwide, including Qatar, where the genetic diversity has not been previously studied.

The most common characteristics that are used to identify different cultivars of date palm are the morphology of leaves, spines, and fruit, which are mainly based on the characterization of introduced date palm cultivars in California (Nixon, 1950). However, morphological traits are often unreliable or imprecise indicators of plant genotype because they are influenced by environmental conditions and vary with the developmental stage of plants. Over the years, many date palm cultivars have been transplanted to areas other than the area of their origin, and they may have been given different names. As a result, a variety may have different names in different areas, or two genetically different varieties may have the same name. This may reduce the genetic diversity of the cultivars, making them vulnerable to biotic and abiotic stresses.

In general, the identification and evaluation of genetic diversity between cultivars on the basis of morphological markers is difficult. The identification of trees is usually not possible until the onset of fruiting, which takes 3 to 5 years. Further, characterizing varieties requires a large set of phenotypic data that are difficult to access statistically and are variable because of environmental effects (Sedra et al., 1993, 1996, 1998). Biochemical markers (isozymes and proteins) are effective in varietal identification (Bennaceur et al., 1991; Fakir et al., 1992; Bendiab et al., 1993). However, they give limited information and are an indirect approach for detecting genomic variation.

Therefore, marker technology for DNA fingerprinting has become increasingly important in recent years to discriminate closely related cultivars. Several marker systems have been used to study the genetic diversity of date palm. In brief, randomly amplified polymor- 
phic DNA (RAPD) fingerprints have been used to identify date palm accessions in Algeria (Benkhalifa, 1999), Morocco (Sedra et al., 1998), Tunisia (Trifi et al., 2000), Saudi Arabia (AlKhalifah and Askari, 2003), and Egypt (Soliman et al., 2003; Adawy et al., 2006). Amplified fragment length polymorphic markers have been applied to study the genetic diversity of date palm cultivars in Egypt and California (Cao and Chao, 2002; El-Assar et al., 2005; Adawy et al., 2006).

Microsatellite or simple-sequence repeat (SSR) molecular markers have been proven to be very powerful in plant diversity analysis because they are locus-specific, have a high degree of polymorphism, have co-dominant inheritance, and are highly reproducible. Numerous reports suggest the usefulness of microsatellite markers for measuring the genetic variability in a wide taxonomic range (Banhos et al., 2008; Chan et al., 2008). These microsatellite markers have been used to assess the genetic diversity and relationships of date palm varieties in Tunisia (Zehdi et al., 2004), Sudan (Elshibli and Korpelainen, 2007), and Oman (Al-Ruqaishi et al., 2008).

In this study, we aimed to investigate the genetic diversity of date palms in Qatar to improve production and reveal the genetic relationships among 12 date palm cultivars using nuclear microsatellite markers. These cultivars have names that were given by farmers after continuous selection, cloning, and exchange.

\section{MATERIAL AND METHODS}

\section{Plant material}

Leaf samples from 59 female date palms, comprising 12 cultivars as shown in Table 1, were collected from different locations as shown in Figure 1. These cultivars represent the diversity of date palm genotypes in the Qatari date palm plantation. Young leaves from mature, randomly sampled trees, were collected and stored at $-80^{\circ} \mathrm{C}$, until DNA extraction.

\begin{tabular}{|c|c|c|c|c|c|}
\hline Cultivar & North $(\mathrm{N})$ & East (E) & West (W) & South (S) & Total \\
\hline Khalas (KHL) & 7 & 5 & 2 & 3 & 17 \\
\hline Shishi (SHI) & 2 & 3 & 2 & 3 & 10 \\
\hline Barhi (BAR) & 2 & 3 & 1 & 1 & 7 \\
\hline Hillali (HIL) & 1 & 3 & 1 & 1 & 6 \\
\hline Khnaizi (KNZ) & 1 & 4 & 2 & 1 & 8 \\
\hline Gar (GAR) & - & 2 & 2 & - & 4 \\
\hline Tanazel (TNZ) & - & - & 1 & - & 1 \\
\hline Nabetseif (NBS) & - & 1 & - & - & 1 \\
\hline Jabri (JAB) & 1 & 1 & - & - & 2 \\
\hline Marzaban (MRZ) & 1 & - & - & - & 1 \\
\hline Iraqi (IRQ) & - & - & - & 1 & 1 \\
\hline Deqlah (DQL) & - & - & - & 1 & 1 \\
\hline Total & 15 & 22 & 11 & 11 & 59 \\
\hline
\end{tabular}

\section{DNA extraction}

The frozen young leaf tissues were cleaned carefully with distilled water to remove the waxy layer, and then $1 \mathrm{~g}$ of each leaf sample was cut into small pieces and ground into a fine powder using liquid nitrogen. The DNA was extracted using the QIAGEN DNeasy Plant 
Maxi kit (QIAGEN, Hilden, Germany), following manufacturer instructions outlined in the DNeasy Plant Handbook. The DNA samples were quantified using a NanoDrop ${ }^{\circledR}$ ND 1000 Spectrophotometer (Thermo Fisher Scientific, Waltham, MA, USA), and the quality was determined by electrophoresis of DNA samples $(2 \mu \mathrm{L})$ on $0.85 \%$ agarose gels and separated at $100 \mathrm{~V}$ for $30 \mathrm{~min}$; following this, the gel was stained with ethidium bromide and viewed under an ultraviolet transilluminator.

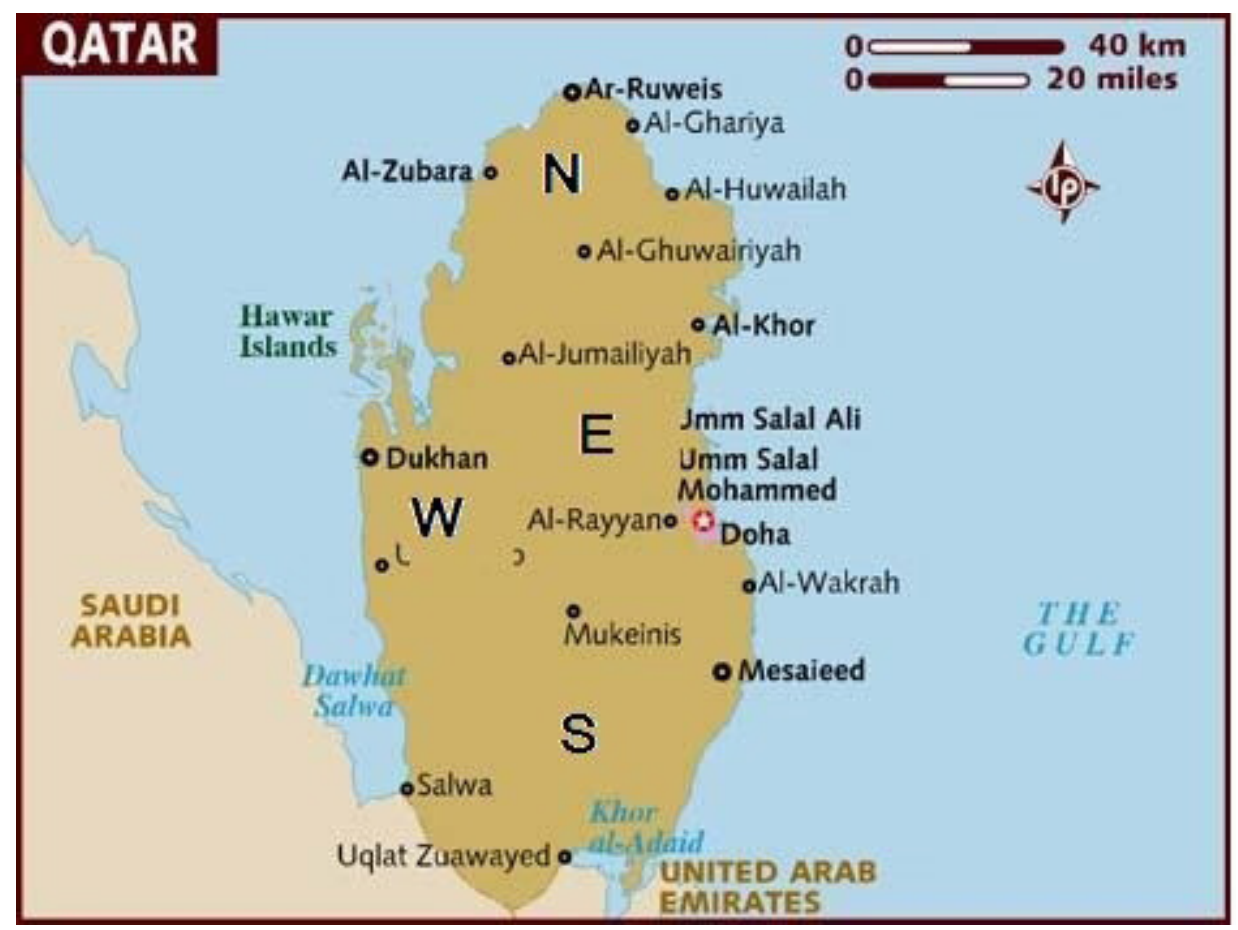

Figure 1. Map of Qatar showing the location of samples.

\section{Microsatellite amplification}

Fourteen labeled primer pairs, as described by Billotte et al. (2004), were synthesized by Applied Biosystems (Life Technologies Europe BV, Belgium) and are presented in Table 2. A polymerase chain reaction (PCR) was performed using a $25-\mu \mathrm{L}$ reaction mixture containing $2 \mu \mathrm{L}$ (5 ng) total genomic DNA, $12.5 \mu \mathrm{L}$ AmpliTaq Gold ${ }^{\circledR} 360$ Mastermix (Applied Biosystems), $1 \mu \mathrm{L} 5 \mu \mathrm{M}$ forward primer (labeled), $1 \mu \mathrm{L}$ reverse primer, and $8.5 \mu \mathrm{L}$ nucleasefree water. Amplification was carried out in a Veriti 96 Well Fast Thermal Cycler (Applied Biosystems) under the following conditions: initial denaturation at $95^{\circ} \mathrm{C}$ for $10 \mathrm{~min} ; 35$ cycles of denaturation at $95^{\circ} \mathrm{C}$ for $30 \mathrm{~s}$, annealing temperature depending on primer for $30 \mathrm{~s}$, and extension at $72^{\circ} \mathrm{C}$ for $1 \mathrm{~min}$; and a final extension at $72^{\circ} \mathrm{C}$ for $7 \mathrm{~min}$.

\section{SSR fragment analysis}

SSRs were screened on a 3130 Genetic Analyzer (Applied Biosystems) by running 
$1 \mu \mathrm{L}$ PCR product mixed with $10 \mu \mathrm{L}$ Hi-Di Formamide and $0.3 \mu \mathrm{L}$ GS500LIZ followed by denaturation at $95^{\circ} \mathrm{C}$ for $3 \mathrm{~min}$. The sample was then kept on ice for genotyping in a $3130 \mathrm{Ge}-$ netic Analyzer. Automatic genotyping and allele scoring were performed by the GeneMapper ${ }^{\mathbb{B}}$ Software v4.0 (Applied Biosystems).

\begin{tabular}{|c|c|c|c|c|}
\hline No. & Primer code & Repeat motif & Primer sequences $\left(5^{\prime}-3^{\prime}\right)$ & Optimal $\operatorname{Tm}\left({ }^{\circ} \mathrm{C}\right)$ \\
\hline 1 & mPdCIR010 & $(\mathrm{GA})_{22}$ & $\begin{array}{l}\text { F: ACCCCGGACGTGAGGTG } \\
\text { R: CGTCGATCTCCTCCTTTGTCTC }\end{array}$ & 55.9 \\
\hline 2 & mPdCIR015 & $(\mathrm{GA})_{15}$ & $\begin{array}{l}\text { F: AGCTGGCTCCTCCCTTCTTA } \\
\text { R: GCTCGGTTGGACTTGTTCT }\end{array}$ & 51.6 \\
\hline 3 & mPdCIR016 & $(\mathrm{GA})_{14}$ & $\begin{array}{l}\text { F: AGCGGGAAATGAAAAGGTAT } \\
\text { R: ATGAAAACGTGCCAAATGTC }\end{array}$ & 51.7 \\
\hline 4 & mPdCIR025 & $(\mathrm{GA})_{22}$ & $\begin{array}{l}\text { F: GCACGAGAAGGCTTATAGT } \\
\text { R: CCCCTCATTAGGATTCTAC }\end{array}$ & 49.3 \\
\hline 5 & mPdCIR032 & $(\mathrm{GA})_{19}$ & $\begin{array}{l}\text { F: CAAATCTTTGCCGTGAG } \\
\text { R: GGTGTGGAGTAATCATGTAGTAG }\end{array}$ & 51.5 \\
\hline 6 & mPdCIR035 & $(\mathrm{GA})_{15}$ & $\begin{array}{l}\text { F: ACAAACGGCGATGGGATTAC } \\
\text { R: CCGCAGCTCACCTCTTCTAT }\end{array}$ & 53.9 \\
\hline 7 & mPdCIR044 & $(\mathrm{GA})_{19}$ & $\begin{array}{l}\text { F: ATGCGGACTACACTATTCTAC } \\
\text { R: GGTGATTGACTTTCTTTGAG }\end{array}$ & 51.7 \\
\hline 8 & mPdCIR048 & $(\mathrm{GA})_{32}$ & $\begin{array}{l}\text { F: CGAGACCTACCTTCAACAAA } \\
\text { R: CCACCAACCAAATCAAACAC }\end{array}$ & 51.4 \\
\hline 9 & mPdCIR057 & $(\mathrm{GA})_{20}$ & $\begin{array}{l}\text { F: AAGCAGCAGCCCTTCCGTAG } \\
\text { R: GTTCTCACTCGCCCAAAAATAC }\end{array}$ & 55.4 \\
\hline 10 & mPdCIR070 & $(\mathrm{GA})_{17}$ & $\begin{array}{l}\text { F: CAAGACCCAAGGCTAAC } \\
\text { R: GGAGGTGGCTTTGTAGTAT }\end{array}$ & 48.7 \\
\hline 11 & mPdCIR078 & $(\mathrm{GA})_{13}$ & $\begin{array}{l}\text { F: TGGATTTCCATTGTGAG } \\
\text { R: CCCGAAGAGACGCTATT }\end{array}$ & 49.6 \\
\hline 12 & mPdCIR085 & $(\mathrm{GA})_{29}$ & $\begin{array}{l}\text { F: GAGAGAGGGTGGTGTTATT } \\
\text { R: TTCATCCAGAACCACAGTA }\end{array}$ & 50.4 \\
\hline 13 & mPdCIR090 & $(\mathrm{GA})_{26}$ & $\begin{array}{l}\text { F: GCAGTCAGTCCCTCATA } \\
\text { R: GCAGTCAGTCCCTCATA }\end{array}$ & 48.6 \\
\hline 14 & mPdCIR093 & $(\mathrm{GA})_{16}$ & $\begin{array}{l}\text { F: CCATTTATCATTCCCTCTCTTG } \\
\text { R: CTTGGTAGCTGCGTTTCTTG }\end{array}$ & 51.8 \\
\hline
\end{tabular}

\section{Data analysis}

Data were analyzed with the PowerMarker software v3.0 (Liu and Muse, 2005) to determine the percentage of heterozygosity, major allele frequency, number of alleles, gene diversity, and polymorphic information content. The total gene diversity $\left(H_{\mathrm{T}}\right)$, mean gene diversity within groups $\left(H_{\mathrm{S}}\right)$, and the genetic differentiation among groups $\left(G_{\mathrm{ST}}\right)$ were calculated using genetix version 4.04 (Belkhir et al., 2001). Analysis of molecular variance (AMOVA) was used to describe the variability among individuals within and between populations using the ARLEQUIN 3.11 software (Excoffier et al., 2005). The phylogenetic relationships among the genotypes and phylogenetic diagrams were drawn using the Past software version 1.91 (Hammer et al., 2001) on the basis of the Hamming similarity index with 100 bootstraps.

\section{RESULTS AND DISCUSSION}

The microsatellites that were examined were highly polymorphic, possessing a great number of alleles. A total of 94 alleles with a mean of 6.71 alleles per locus were scored. The number of alleles per locus varied from 3 (primer mPdCIR090) to 11 (primers mPdCIR010 
and mPdCIR015 (Table 3). The numbers of alleles per locus detected in this study were lower than those scored by Zehdi et al. (2004), who recognized 7.14 alleles per locus when examining 46 Tunisian date palm accessions by using 14 microsatellite loci. On the other hand, Elshibli and Korpelainen (2007) identified 21.4 alleles per locus, which is more than the number of alleles per locus detected in this study. This may be a result of using a greater number of microsatellite loci (16) and different genotypes - 68 Sudan and Morocco date palm accessions.

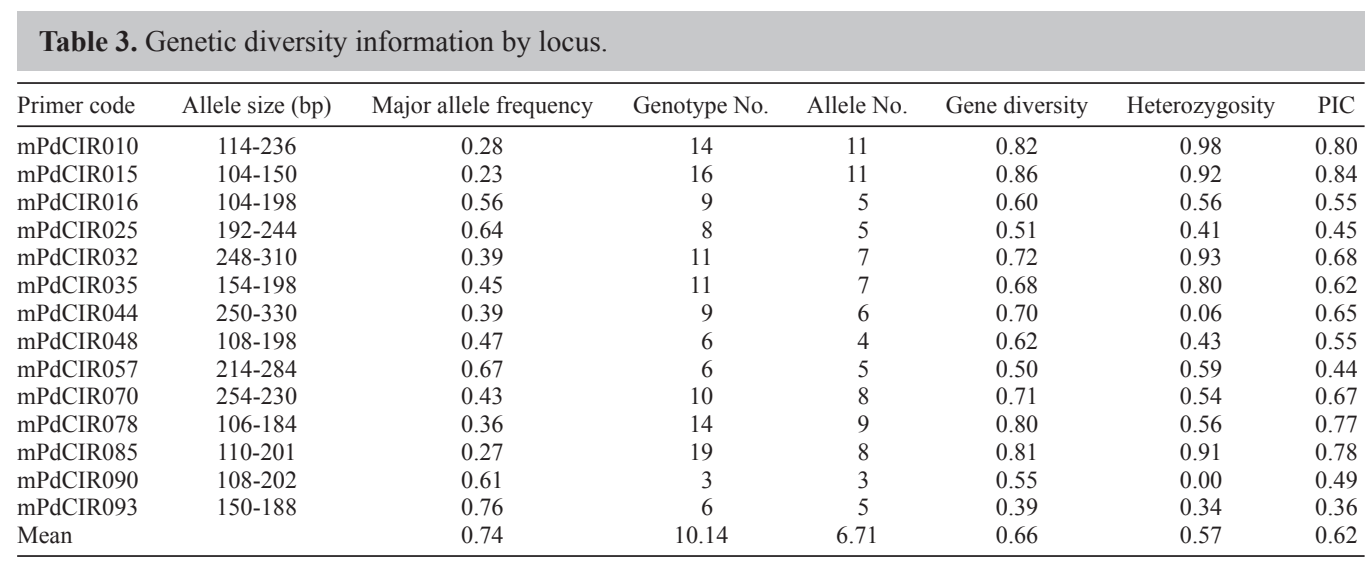

$\mathrm{PIC}=$ polymorphic information content.

The primer mPdCIR063 did not amplify a PCR product in our samples. Zehdi et al. (2004) found that of 16 primer pairs tested in Tunisian date palms, only 14 yielded successful amplification. However, 10 of 16 (62.5\%) primer pairs were selected for full analysis based on the quality of the amplification in the study by Al-Ruqaishi et al. (2008) in Omani date palm.

The 14 primers used in this study successfully produced clear amplified SSR bands with sizes ranging from $104 \mathrm{bp}$ (primers mPdCIR015 and mPdCIR016) to $330 \mathrm{bp}$ (primer mPdCIR044) (Table 3). These results were similar to those of Ahmed and Al-Qaradawi (2009), where the band sizes ranged from 100 to $300 \mathrm{bp}$. Interestingly, the 14 microsatellite primers and 59 female date palm samples used in this study formed 142 genotypes with a mean of 10.14 genotypes per primer (Table 3). The highest was 19 different genotypes scored with primer mPdCIR085, but only 3 different genotypes were scored with primer mPdCIR090.

The mean gene diversity was 0.66 (Table 3), and it ranged from 0.39 (locus mPdCIR093) to 0.86 (locus mPdCIR015), indicating that the Qatari date palm collection is characterized by a high degree of genetic diversity. This level of gene diversity is close to that from the data reported for the Tunisian date palm germplasm (Zehdi et al., 2004) and less than the 0.853 reported for the Sudanese date palm (Elshibli and Korpelainen, 2007). This high level of diversity is expected because of the unique mechanism that is responsible for generating SSR allelic diversity by replication slippage. Replication slippage is thought to occur more frequently than single nucleotide mutations and insertion/deletion events, which generate the polymorphisms that are detected by RAPD analysis (Powell et al., 1996).

The observed heterozygosity ranged from 0 (marker mPdCIRO90) to 98\% (marker mPdCIRO10), with an average of 57\% (Table 3), Homozygous alleles showed only 1 peak, while heterozygous alleles showed 2 peaks (Figures 2 and 3). However, except 3 loci 
(mPdCIRO90, mPdCIR093, and mPdCIR025), most of the studied loci showed heterozygosity over $50 \%$, which is expected in date palms because they are outcross trees. The percentage of observed heterozygosity in this study is much lower than 0.84 and 0.82 in Sudan and Morocco date palm cultivars, respectively (Elshibli and Korpelainen, 2007).

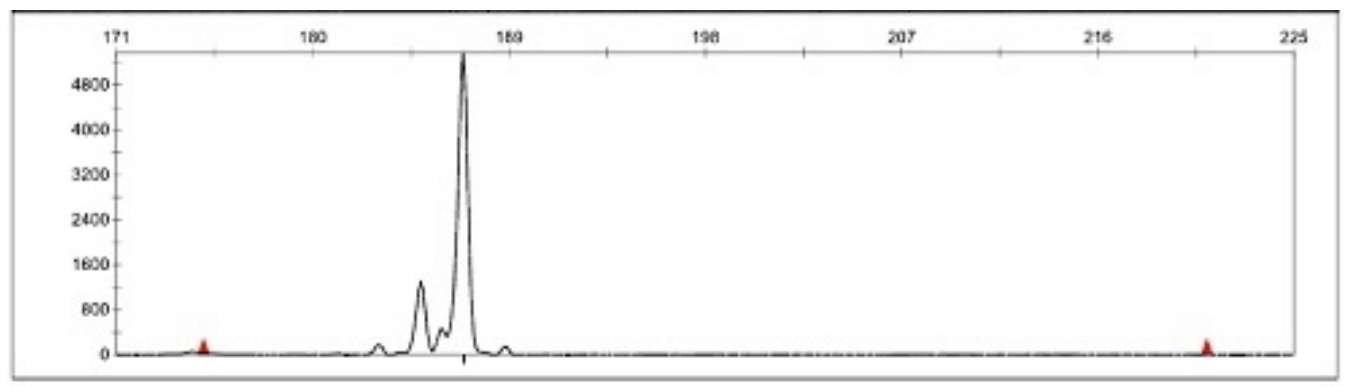

Figure 2. Homozygous alleles show only 1 peak. Scoring was performed by the GeneMapper software. The y-axis indicates the peak height, and the $\mathrm{x}$-axis indicates the peak size in base pairs.

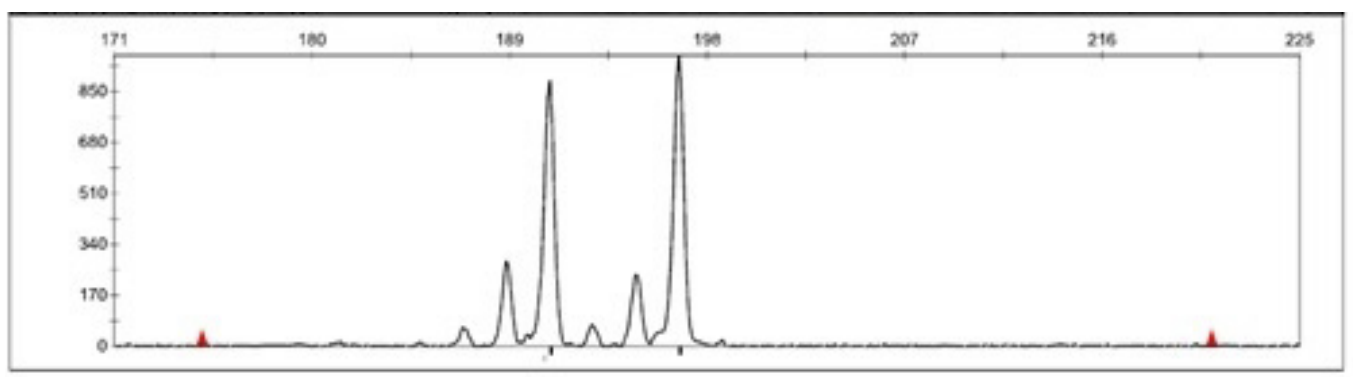

Figure 3. Heterozygous alleles show 2 peaks. Scoring was performed by the GeneMapper software. The y-axis indicates the peak height, and the $\mathrm{x}$-axis indicates the peak size in base pairs.

The polymorphism information content value, which is commonly used in genetics as a measure of polymorphism for a marker locus used in linkage analysis, ranged between 0.36 (mPdCIR093) and 0.84 (mPdCIR015), with an average of 0.62. This average value is similar to the value of 0.65 in Guinea yam using 15 microsatellite loci (Obidiegwu et al., 2009).

$H_{\mathrm{T}}, H_{\mathrm{S}}$, and $G_{\mathrm{ST}}$ values are reported in Table $4 . H_{\mathrm{S}}$ and $G_{\mathrm{ST}}$ values are nearly similar, suggesting that the $H_{\mathrm{T}}$ is attributable either to the gene diversity within populations or the genetic differentiation among populations. For instance, the multiloci $H_{\mathrm{S}}, H_{\mathrm{T}}$, and $G_{\mathrm{ST}}$ values are $0.3751,0.6709$, and 0.4409 , respectively. We may therefore assume that $44 \%$ of the variability is explained at the inter-population level, while $56 \%$ of this variability is maintained within individuals. However, the loci mPdCIR044, mPdCIR057, mPdCIR090, and mPdCIR093 revealed that the $H_{\mathrm{T}}$ is explained at the inter-population level.

Additionally, AMOVA to determine the partitioning of the molecular variance among the defined populations corroborates this result. In fact, significant percentages of variance were scored among the defined populations $(24.81 \%$; $\mathrm{P}<0.002 \%)$ and within individuals $(88.82 \% ; \mathrm{P}<0.002 \%)$. This scored AMOVA partition indicates the presence of considerable genotypic variation among the sampled cultivars. 
Table 4. Total gene diversity $\left(H_{\mathrm{T}}\right)$, mean gene diversity within populations $\left(H_{\mathrm{S}}\right)$, and genetic differentiation among populations $\left(G_{\mathrm{ST}}\right)$ were estimated using Genetix 4.04.

\begin{tabular}{lcccc}
\hline Locus No. & Locus code & $H_{\mathrm{T}}$ & $H_{\mathrm{S}}$ & $G_{\text {ST }}$ \\
\hline 1 & R010 & 0.81 & 0.56 & 0.31 \\
2 & R015 & 0.85 & 0.52 & 0.39 \\
3 & R016 & 0.63 & 0.36 & 0.42 \\
4 & R025 & 0.46 & 0.29 & 0.36 \\
5 & R032 & 0.76 & 0.47 & 0.38 \\
6 & R035 & 0.65 & 0.44 & 0.61 \\
7 & R044 & 0.64 & 0.25 & 0.48 \\
8 & R048 & 0.68 & 0.36 & 0.40 \\
9 & R057 & 0.31 & 0.19 & 0.41 \\
10 & R070 & 0.74 & 0.44 & 0.31 \\
1 & R078 & 0.86 & 0.45 & 0.78 \\
12 & R085 & 0.81 & 0.56 & 0.57 \\
13 & R090 & 0.66 & 0.14 & 0.44 \\
\hline Multilocus & R093 & 0.54 & 0.23 & 0.67 \\
\hline
\end{tabular}

The fixation index $\left(F_{\mathrm{ST}}\right)$ values between different populations based on 14 microsatellite loci varied from 0.03226 to 0.40514 (Table 5). The Qatari populations Khalas, Shishi, Barhi, Hillali, Khnaizi, Gar, and Jabri showed significant differentiation compared to all other populations. The average value of $F_{\mathrm{ST}}$ was 0.24814 , indicating that about $24.81 \%$ of the genetic variation was present among populations, which correlates with AMOVA.

Table 5. Fixation index $\left(F_{\mathrm{ST}}\right)$ values of Qatari date palm populations (pop) based on 14 microsatellite loci.

\begin{tabular}{|c|c|c|c|c|c|c|c|c|c|c|c|c|}
\hline Pop & $\begin{array}{l}\text { Khalas } \\
\text { (KHL) }\end{array}$ & $\begin{array}{l}\text { Shishi } \\
\text { (SHI) }\end{array}$ & $\begin{array}{l}\text { Barhi } \\
\text { (BAR) }\end{array}$ & $\begin{array}{c}\text { Hillali } \\
(\mathrm{HIL})\end{array}$ & $\begin{array}{c}\text { Khnaizi } \\
\text { (KNZ) }\end{array}$ & $\begin{array}{c}\text { Gar } \\
(\mathrm{GAR})\end{array}$ & $\begin{array}{c}\text { Tanazel } \\
\text { (TNZ) }\end{array}$ & $\begin{array}{c}\text { Nabetseif } \\
\text { (NBS) }\end{array}$ & $\begin{array}{c}\text { Jabri } \\
\text { (JAB) }\end{array}$ & $\begin{array}{c}\text { Marzaban } \\
\text { (MRZ) }\end{array}$ & $\begin{array}{l}\text { Iraqi } \\
\text { (IRQ) }\end{array}$ & $\begin{array}{l}\text { Deqlah } \\
\text { (DQL) }\end{array}$ \\
\hline Shishi (SHI) & $0.13368^{*}$ & - & & & & & & & & & & \\
\hline Barhi (BAR) & $0.25377^{*}$ & $0.21215^{*}$ & - & & & & & & & & & \\
\hline Hillali (HIL) & $0.24239 *$ & $0.20642 *$ & $0.20645^{*}$ & - & & & & & & & & \\
\hline Khnaizi (KNZ) & $0.24953^{*}$ & $0.26626^{*}$ & $0.31484^{*}$ & $0.21357^{*}$ & - & & & & & & & \\
\hline Gar (GAR) & $0.20639^{*}$ & $0.22351^{*}$ & $0.22096^{*}$ & $0.26411^{*}$ & $0.21121^{*}$ & - & & & & & & \\
\hline Tanazel (TNZ) & $0.11116^{*}$ & $0.16352 *$ & $0.32771^{*}$ & $0.28638^{*}$ & $0.30074 *$ & $0.16755^{*}$ & - & & & & & \\
\hline Nabetseif (NBS) & 0.13163 & 0.22739 & 0.37771 & 0.18850 & 0.18321 & 0.29492 & 0.17363 & - & & & & \\
\hline Jabri (JAB) & 0.33832 & 0.32287 & 0.35647 & 0.19604 & 0.13652 & 0.25286 & 0.32991 & 0.16129 & - & & & \\
\hline Marzaban (MRZ) & 0.14977 & 0.26848 & 0.35144 & 0.18831 & 0.29929 & 0.25809 & 0.23587 & 0.27778 & 0.31707 & - & & \\
\hline Iraqi (IRQ) & 0.20179 & 0.31358 & 0.40514 & 0.31222 & 0.28300 & 0.32605 & 0.31429 & 0.24324 & 0.28571 & 0.16667 & - & \\
\hline Deqlah (DQL) & 0.20940 & 0.28131 & 0.35230 & 0.21189 & 0.32728 & 0.34247 & 0.30494 & 0.1250 & 0.26829 & 0.03226 & 0.05882 & - \\
\hline
\end{tabular}

Moreover, environmental effects and interactions between environmental and genetic factors may strongly contribute to the fruit traits of date palm. The long history of date palm domestication with an unknown origin (Wrigley, 1995) and the nature of date palm culture may have played an important role in the composition of date palm genomes. Considering the observed weak clustering of the cultivars in this study, we suggest that these cultivars are not a result of intact cloning processes. We expect that the propagation cycles performed by farmers were disrupted by a mixture of plants derived from seeds. This may occur because propagation by seeds is much faster; seeds germinate easily and are available in large numbers, and sometimes seeds germinate just under their mother trees. This suggestion can be supported also by the high genetic diversity that was observed within groups.

On the other hand, pollination is mainly mechanical. The farmers depend on few selected males for the pollination of female trees. Male trees are selected for fruit quality 
and are exchanged between farmers (Osman, 2001). Pollen grains of more than one male are sometimes mixed and used for pollination. New cultivars are the result of a continuous selection process that is carried out by farmers in their fields following sexual reproduction. The exchange of propagules, which are a mix of vegetative and seed-propagated materials, is conducted between farmers. All these processes together may result in a mixed date palm genome within the country.

A dissimilarity matrix between Qatari date palm cultivars showed an average dissimilarity coefficient that ranged from 0.036 to 0.962 . The cultivars studied here were highly divergent at the DNA level. The lowest dissimilarity coefficient value was observed between Khalas N2 and Khalas E3 (0.036), which seem to be the 2 closest individuals with $96.4 \%$ similarity and can be closely grouped (Figure 4). The next close cultivars have a dissimilarity coefficient of 0.07 (Khalas S2 and Khalas E2). A dissimilarity coefficient value of 0.96 was obtained between Iraqi S2 and Khnaizi W1, indicating that the distance of their relationship may be due to introducing the Iraqi cultivar in the Qatari area. The next dissimilar cultivars, with a value of $89 \%$, were Marzaban N1 and Shaishi N1.

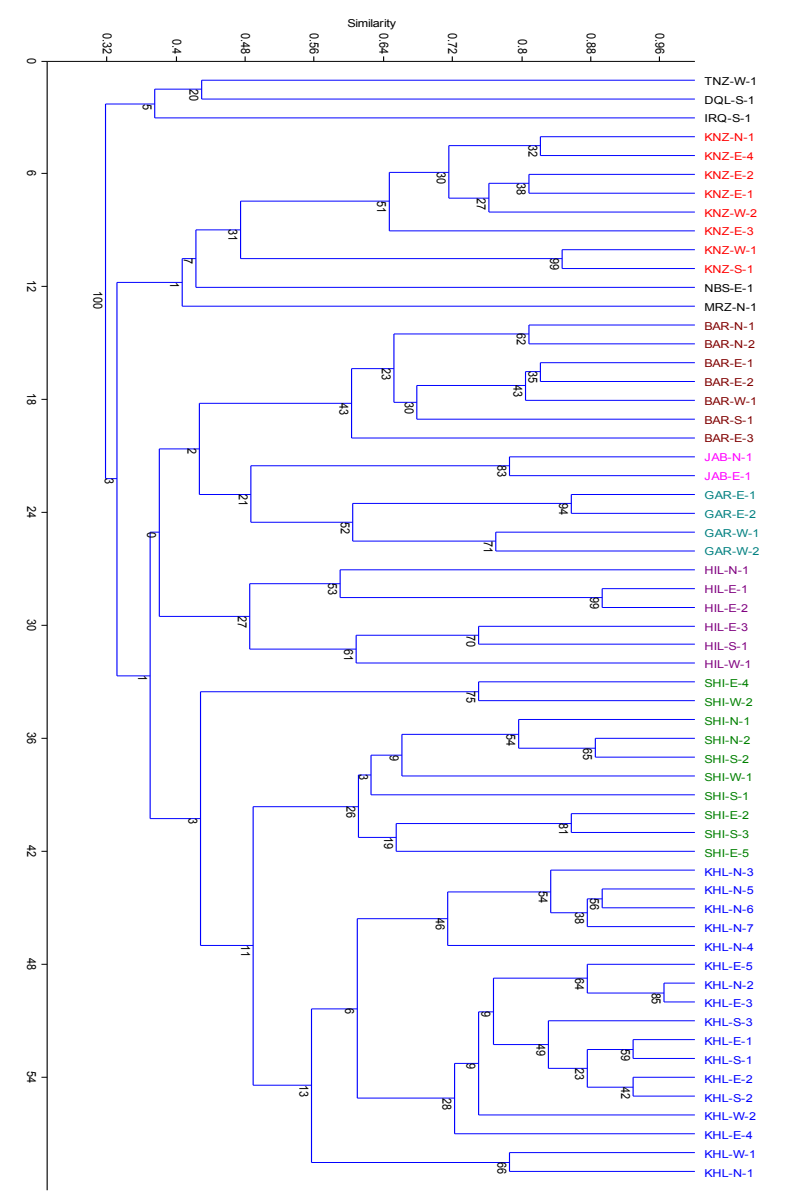

Figure 4. Phylogram of Qatari date palms based on the Hamming similarity measure with 100 bootstraps. 
Molecular markers can provide an effective tool for the efficient selection of desired agronomic traits because they are based on the plant genotypes. Thus, they are independent of environmental variation. Several molecular markers are currently employed. Of these, SSRs or microsatellites are the most widely used marker type. SSRs are very common and hypervariable for repetitive DNA motifs in the genomes of eukaryotes (Rallo et al., 2000; Van der Schoot et al., 2000). All of the cultivars displayed different levels of dissimilarity, but they were still grouped together (Figure 4). The variation or polymorphism of SSRs is thought to be a result of polymerase slippage during DNA replication or unequal crossing over (Levinson and Gutman, 1987). Fortunately, the revealed SSR alleles were successfully used to molecularly discriminate a nearly unlimited number of date palm cultivars. Compared to other studies of date palms, the scored percentage of resolution is higher than those observed using isoenzymes (Booij et al., 1995; Salem et al., 2001) and plastid DNA haplotypes (Sakka, 2003). These authors reported 69,93 , and $71 \%$ resolving power, respectively. Our results provided neutral molecular markers that are powerfully suitable for cultivar identification. Their transfer to other laboratories over the world would be of great interest to label offshoots, any other plant material at an early stage, and in vitro plantlets. Our data provide evidence for the possibility of using these powerful markers as descriptors in the certification and control of origin labels of date palm material.

The phylogenetic diagram illustrates the divergence between the studied Qatari date palm cultivars (Figure 4) and suggests 4 branches. The Iraqi, Diqla, and Tanazel cultivars were clustered separately from the rest of the cultivars. The phylogenetic tree showed 3 major clusters. The first cluster included 3 cultivars (Khnaizi, NabetSaef, and Marzaban), the second cluster contained 4 cultivars (Barhi, Jabri, Qar, and Hillali), and Khalas and Shaishi were grouped in a separate cluster (Figure 4). A consensus tree for 58 Qatari date palms representing 12 cultivars (Figure 4) exhibited weak clustering relationships with bootstrapping values.

Genetic diversity is desirable for long-term crop improvement and reduced vulnerability to important crop diseases. Measurements of genetic diversity can be used in breeding programs to increase the genetic variation in populations by crossing cultivars with a high level of genetic distance and for the introgression of exotic germplasm. Molecular genetic diversity estimates are extremely useful for intellectual property protection, particularly in the determination of essential derivation. The genetic diversity estimates based on molecular marker data may be compared to a minimum genetic distance, which indicates that two cultivars are not essentially derived (Lefebvre et al., 2001).

\section{ACKNOWLEDGMENTS}

Research supported by the grant from the International Center for Agricultural Research in the Dry Areas (ICARDA), under the scheme of Development of Sustainable Date Palm Production Systems in the GCC Countries of the Arabian Peninsula.

\section{REFERENCES}

Abulfatih HA, El-Sharief Abdalla OA and Al-Yousuf AH (1999). Desertification and Natural Resources in Qatar. Department of Agriculture and Water Research, Ministry of Municipal Affairs and Agriculture, Doha.

Adawy SS, Hussein EHA, Ismail SEME and El-Itriby HA (2006). Genomic Diversity in Date Palm (Phoenix dactylifera L.) as Revealed by AFLPs in Comparison to RAPDs and ISSRs. In: Abstracts of 3rd International Date Palm Conference, Abu Dhabi. 
Ahmed TA and Al-Qaradawi AY (2009). Molecular phylogeny of Qatari date palm genotypes using simple sequence repeats markers. Biotechnology 8: 126-131.

Al-Khalifah NS and Askari E (2003). Molecular phylogeny of date palm (Phoenix dactylifera L.) cultivars from Saudi Arabia by DNA fingerprinting. Theor. Appl. Genet. 107: 1266-1270.

Al-Ruqaishi IA, Davey M, Alderson P and Mayes S (2008). Genetic relationships and genotype tracing in date palms (Phoenix dactylifera L.) in Oman, based on microsatellite markers. Plant Genet. Resour. 6: 70-72.

Banhos A, Hrbek T, Gravena W, Sanaiotti T, et al. (2008). Genomic resources for the conservation and management of the harpy eagle (Harpia harpyja, Falconiformes, Accipitridae). Genet. Mol. Biol. 31: 146-154.

Barrow SC (1998). A monograph of Phoenix L. (Palmae: Coryphoideae). Kew Bull. 53: 513-575.

Belkhir K, Borsa P, Chikhi L, Raufaste N, et al. (2001). Genetix 4.02, Logiciel Sous Windows Pour la Génétique des Populations. Laboratoire Génome, Populations, Interactions, CNRS UMR 5000, Université Montpellier II, Montpellier.

Bendiab K, Baaziz M, Brakez Z and Sedra MH (1993). Correlation of isoenzyme polymorphism and Bayoud-disease resistance in date palm cultivars and progeny. Euphytica 65 : 23-32.

Benkhalifa A (1999). Gestion de la Diversité Génétique du Palmier Dattier en Algérie. Paper Presented at the Workshop Constitution et Organisation D'équipes de Recherche Scientifique dans les Domaines de Foresterie et des Arbres Fruitiers, Marrakech.

Bennaceur M, Lanaud C, Chevallier MH and Bounaga N (1991). Genetic diversity of the date palm (Phoenix dactylifera L.) from Algeria revealed by enzyme markers. Plant Breed. 107: 56-69.

Billotte N, Marseillac N, Brottier P, Noyer JL, et al. (2004). Nuclear microsatellite markers for date palm (Phoenix dactylifera L.): characterization and utility across the genus Phoenix and in other palm genera. Mol. Ecol. Notes 4: 256-258.

Booij L, Montfort S and Ferry M (1995). Characterization of thirteen date palm (Phoenix dactylifera L.) cultivars by enzyme electrophoresis using the PhastSystem. J. Plant Physiol. 145: 62-66.

Cao BR and Chao CT (2002). Identification of date cultivars in California using AFLP markers. HortScience 37: $966-968$.

Chan CH, Zhao Y, Cheung MY and Chambers GK (2008). Isolation and characterization of microsatellites in the kakerori (Pomarea ÿharacter) using feathers as source of DNA. Conserv. Genet. 9: 1067-1070.

El-Assar AM, Krueger RR, Devanand PS and Chao CT (2005). Genetic analysis of Egyptian date (Phoenix dactylifera L.) accessions using AFLP markers. Genet. Resour. Crop Evol. 52: 601-607.

Elshibli S and Korpelainen H (2007). Microsatellite markers reveal high genetic diversity in date palm (Phoenix dactylifera L.) germplasm from Sudan. Genetica 134: 251-260.

Excoffier L, Laval G and Schneider S (2005). Arlequin (version 3.0): an integrated software package for population genetics data analysis. Evol. Bioinform. Online 1: 47-50.

Fakir S, Carbonnier J and Birouk A (1992). Analyse du Polymorphisme Enzymatique et Proteique des Cultivars Maricains du Palmier Dattier (Phoenix dactylifera L.). In: Complexes D'especes, Flux de Genes et Ressources Genetiques des Plantes. Actes Colloq Int. Lavoisier, Paris, 645.

General Department for Agriculture Research and Development (2008). Agricultural Economics and Statistics Section. In: Cropped Areas and Production Bulletin Season 2007-2008, Doha-Qatar.

Hammer Ø, Harper DAT and Ryan PD (2001). Past: paleontological statistics software package for education and data analysis. Palaeontol. Electron. 4: Article 4.

Hanachi S, Benkhalifa A, Khirtri D and Brac de la Perrière RA (1998). Inventaire Varietal de la Palmeraie Algerienne [Varietal Inventory of the Algerian Palms]. CDARS, Anep Rouiba.

Lefebvre V, Goffinet B, Chauvet JC, Caromel B, et al. (2001). Evaluation of genetic distances between pepper inbred lines for cultivar protection purposes: comparison of AFLP, RAPD and phenotypic data. Theor. Appl. Genet. 102: 741-750.

Levinson G and Gutman GA (1987). Slipped-strand mispairing: a major mechanism for DNA sequence evolution. Mol. Biol. Evol. 4: 203-221.

Liu K and Muse SV (2005). PowerMarker: an integrated analysis environment for genetic marker analysis. Bioinformatics 21: $2128-2129$.

Malek JA (2010). Next generation DNA sequencing applied to the date palm tree (Phoenix dactylifera). Acta Hortic. 882: 249-252.

Nixon RW (1950). Imported Cultivars of Dates in the United States. United States Department of Agriculture Circular No. 834, Washington, D.C.

Obidiegwu JE, Kolesnikova-Allen M, Ene-Obong EE, Muoneke CO, et al. (2009). SSR markers reveal diversity in Guinea yam (Dioscorea cayenensis/D. rotundata) core set. Afr. J. Biotechnol. 8: 2730-2739.

Oihabi A (2000). Technical Report: Date Palm Genetic Resources in North Africa. In: Proceedings of the Date Palm International Symposium, Namibia, 333-335. 
Osman AMA (2001). Development of Date Palm Culture in Republic of Sudan. Paper Presented at a Workshop on Date Palm Culture and Dates Production in Republic of Sudan. Date Palm Research and Development Network, Khartoum.

Powell W, Morgante M, Andre C, Hanafey M, et al. (1996). The comparison of RFLP, RAPD, AFLP and SSR (microsatellite) markers for germplasm analysis. Mol. Breed. 2: 225-238.

Rallo P, Dorado G and Martín A (2000). Development of simple sequence repeats (SSRs) in olive tree (Olea europaea L.). Theor. Appl. Genet. 101: 984-989.

Sakka H (2003). Analyse de la Diversité Génétique Chez le Palmier Dattier (Phoenix dactylifera L.): Polymorphisme de L'ADN Chloroplastique. Doctoral thesis, Universite Tunis El Manar, Faculté des Sciences de Tunis, Tunis.

Salem AOM, Trifi M, Sakka H, Rhouma A, et al. (2001). Genetic inheritance analysis of four enzymatic systems in datepalm (Phoenix dactylifera L.). Genet. Resour. Crop Evol. 48: 361-368.

Sedra MH, Filali HEL and Frira D (1993). Observations sur quelques caracteristiques phenotypiques et agronomiques du fruit des varieties et clones du palmier dattier selectionnes. Al Awamia 82: 105-120.

Sedra MH, Filali HEL, Benzine A, Allaoui M, et al. (1996). La palmeraie dattière marocaine: evaluation du patrimoine phenicicole. Fruits 1: 247-259.

Sedra MH, Lashermes P, Trouslot P, Combes MC, et al. (1998). Identification and genetic diversity analysis of date palm (Phoenix dactylifera L.) varieties from Morocco using RAPD markers. Euphytica 103: 75-82.

Soliman SS, Ali BA and Ahmed MMM (2003). Genetic comparisons of Egyptian date palm cultivars (Phoenix dactylifera L.) by RAPD-PCR. Afr. J. Biotechnol. 2: 86-87.

Trifi M, Rhouma A and Marrakchi M (2000). Phylogenetic relationships in Tunisian date-palm (Phoenix dactylifera $\mathrm{L}$.) germplasm collection using DNA amplification fingerprinting. Agronomie 20: 665-671.

Van der Schoot J, Pospĩsková M, Vosman B and Smulders MJM (2000). Development and characterization of microsatellite markers in black poplar (Populus nigra L.). Theor. Appl. Genet. 101: 317-322.

Wrigley G (1995). Date palm (Phoenix dactylifera L.). In: The evolution of crop plants (Smartt J and Simmonds NW, eds.). Longman, London, 399-403.

Zehdi S, Trifi M, Billotte N, Marrakchi M, et al. (2004). Genetic diversity of Tunisian date palms (Phoenix dactylifera L.) revealed by nuclear microsatellite polymorphism. Hereditas 141: 278-287. 